\title{
The GH/IGF-I axis in the brushtail possum (Trichosurus vulpecula) pouch young
}

\author{
M C Saunders, R T Gemmell ${ }^{1}$ and J D Curlewis \\ School of Biomedical Sciences, Department of Physiology and Pharmacology, University of Queensland, Brisbane, Queensland 4072, Australia \\ ${ }^{1}$ Anatomical Sciences, University of Queensland, Brisbane 4072, Australia \\ (Requests for offprints should be addressed to J D Curlewis; Email: j.curlewis@mailbox.uq.edu.au)
}

\begin{abstract}
Plasma and pituitary GH concentrations and liver GH receptor (GHR), IGF-I and IGF-binding protein-3 (IGFBP-3) mRNA expression were determined in brushtail possum (Trichosurus vulpecula) pouch young aged 12-150 days post-partum and in adults. Mean plasma $\mathrm{GH}$ concentrations were highest, measuring around $150 \mathrm{ng} / \mathrm{ml}$, from 12 to 100 days post-partum, and thereafter declined so that by 150 days post-partum levels were not significantly different from those in adults $(10.8 \pm 1.8 \mathrm{ng} / \mathrm{ml}$ (S.E.M.)). In contrast to plasma levels, pituitary GH content increased markedly throughout pouch life, with an 87-fold increase between 12 and 150 days post-partum. However, when expressed per gram body weight, pituitary content was relatively constant between 25 and 150 days post-partum, indicating that the decline in plasma GH after 100 days post-partum
\end{abstract}

was not due to decreased synthesis and/or storage of GH in the pituitary gland. Expression of GHR, IGF-I and IGFBP-3 mRNAs was determined by semi-quantitative RT-PCR. Liver GHR and IGF-I mRNA expression were low at 12 and 25 days post-partum and did not show sustained and significant increases $(P<0 \cdot 05)$ until 125 and 150 days post-partum. IGFBP-3 expression was also low at 12 days post-partum but then increased rapidly to a maximum at 50 days post-partum and thereafter declined. For all three mRNAs, liver expression at day 150 was not significantly different from that in adults. These patterns of gene expression for GHR and IGF-I suggest that the possum liver is resistant to the high plasma GH concentrations during early pouch life and in this way is similar to the fetal liver of some eutherian mammals.

Journal of Endocrinology (2003) 176, 219-225

\section{Introduction}

In contrast to eutherian mammals, marsupials have a very short period of growth and development in utero and give birth to a relatively immature pouch young that then undergoes a lengthy period of further growth and development in the mother's pouch. We have recently shown that for two species of marsupial, the bandicoot (Saunders et al. 2000) and brushtail possum (Saunders et al. 2002), plasma growth hormone $(\mathrm{GH})$ concentrations are very high for about the first half of pouch life before gradually declining to adult levels. Growth rate is slower during the first half of pouch life (Gemmell \& Hendrikz 1993) when plasma GH concentrations are at their highest (Saunders et al. 2002), which suggests that GH does not play a major role in stimulating growth at this time. One possible explanation for this apparent paradox would be if $\mathrm{GH}-$ stimulated insulin-like growth factor-I (IGF-I) production from the liver were low during early pouch life and then subsequently increased around the time of increasing growth rate after about 96 days post-partum. In this study of the brushtail possum (Trichosurus vulpecula), we therefore set out to quantify gene expression for two elements of this pathway in the liver, GH receptor (GHR) and IGF-I. In several eutherian species, expression of both genes is stimulated by GH as well as other hormones (Mathews et al. 1986, 1989, Sauerwein et al. 1991, Ambler et al. 1992, Lemmey et al. 1997). We also chose to quantify liver gene expression of IGF-binding protein-3 (IGFBP-3) because this is also stimulated by GH (Lemmey et al. 1997) and so could provide another indicator of tissue responsiveness to GH. In order to measure expression of these genes, it was first necessary to obtain the possum sequence for each gene so that PCR primers could be designed.

\section{Materials and Methods}

Animals and collection of blood and tissue

A breeding colony of brushtail possums was maintained as previously described (Saunders et al. 2002) with food and water freely provided. Blood, pituitary gland and liver samples were obtained from brushtail possum adults and pouch young aged $12,25,50,75,100,125$ and 150 days post-partum ( $n \geq 3$ at each age). All pouch young were bred in captivity and their ages precisely known from 

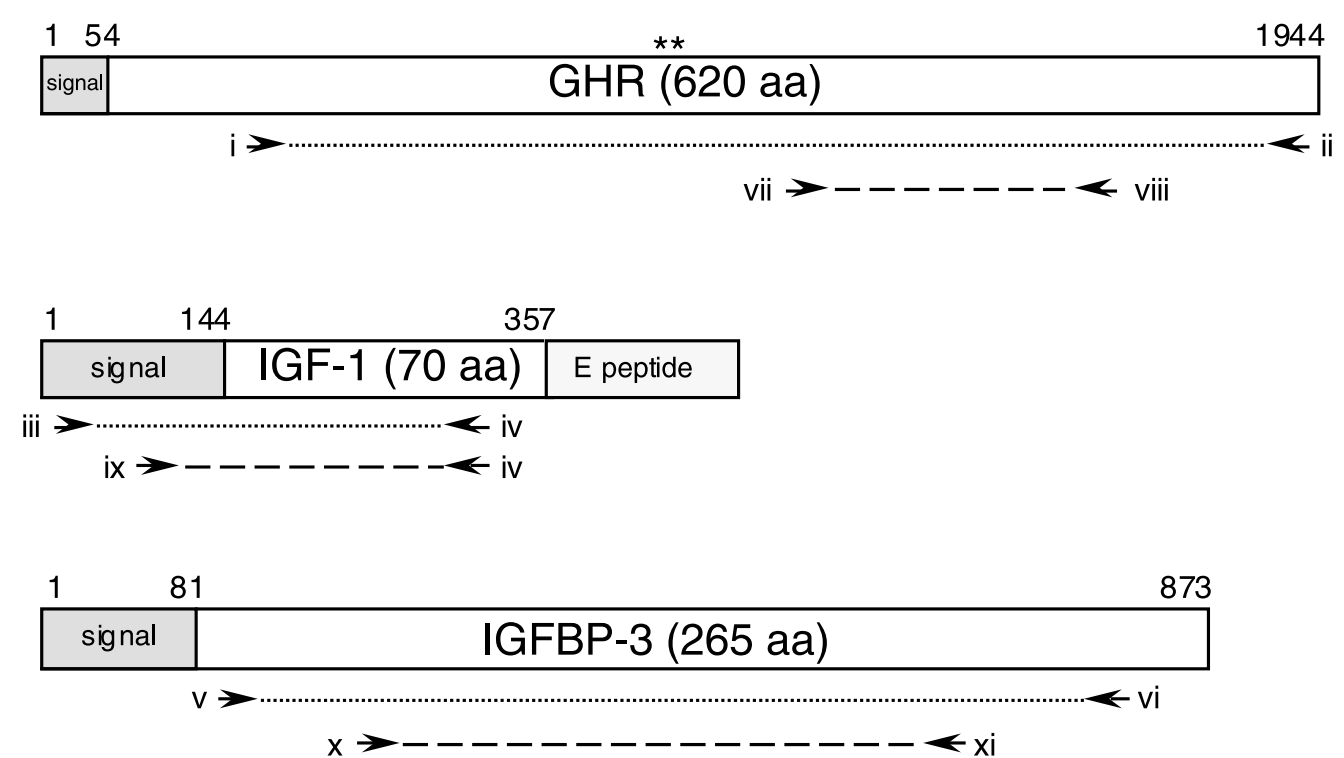

Figure 1 Schematic diagram of CDNAs encoding GHR, IGF-I and IGFBP-3. The approximate positions of primer combinations and PCR products used for cloning (dotted line) and semi-quantitative RT-PCR (dashed line) are shown; ** indicates the transmembrane region of GHR. The $5^{\prime}$ - and $3^{\prime}$ - untranslated regions are not shown.

regular examination of pouches to identify the day of birth. The ages of 12-day-old pouch young were accurate to within 1 day whereas older age groups were \pm 3 days. All samples were collected during the normal breeding season (Gemmell 1990) between 0900 and $1300 \mathrm{~h}$. A permit for the collection and maintenance of possums was obtained from the Queensland National Parks and Wildlife Service and experimental procedures were approved by the Animal Experimentation Ethics Committee of the University of Queensland.

Blood samples were obtained by cardiac puncture from pouch young and adults that were lightly anaesthetised with a 3\% halothane (Rhone Merieux, West Footscray, Australia) in oxygen mixture $(0.51 / \mathrm{min})$. All blood samples were centrifuged $\left(2000 \mathrm{~g}, 10 \mathrm{~min}, 4^{\circ} \mathrm{C}\right)$ and the plasma collected and stored at $-20{ }^{\circ} \mathrm{C}$ prior to assay for $\mathrm{GH}$. After blood was collected, animals were killed by intracardiac injection of Nembutal (pentabarbitone sodium $60 \mathrm{mg} / \mathrm{ml}$; Boehringer Ingelheim, Artarmon, Australia; $0.25 \mathrm{ml} / 100 \mathrm{~g}$ ). The pituitary gland (only from pouch young) and a piece of liver (pouch young and adults) were removed, frozen on dry ice and then stored at $-80{ }^{\circ} \mathrm{C}$ until pituitary homogenates were prepared or RNA was extracted from liver tissue.

\section{Pituitary gland homogenates}

Pituitary glands were homogenised on ice, in $500 \mu \mathrm{l}$ ammonium bicarbonate $(0.2 \mathrm{M}, \mathrm{pH} 8 \cdot 3)$ with a glassTeflon homogeniser. Homogenates were transferred to $1.5 \mathrm{ml}$ tubes and centrifuged at $10000 \mathrm{~g}$ for $5 \mathrm{~min}$ in a microcentrifuge and then the supernatant was stored at $20{ }^{\circ} \mathrm{C}$ until $\mathrm{GH}$ assays were performed.

\section{GH RIA}

Plasma and pituitary gland GH concentrations were determined in a heterologous RIA (Saunders et al. 2002). This assay uses an antiserum against wallaby $\mathrm{GH}$ (wGH) (G5/3; Curlewis \& McNeilly (1992)), brushtail possum $\mathrm{GH}$ purified from pituitary glands as standard and wGH (cWB-9) as the radioiodinated ligand. Intra- and inter-assay coefficients of variation were 3.5 and $18.0 \%$ respectively and the assay sensitivity was $0.8 \mathrm{ng} / \mathrm{ml}$.

\section{PCR cloning of possum GHR, IGF-I and IGFBP-3}

cDNA sequences for GHR, IGF-I and IGFBP-3 had not been reported for any marsupial species when these experiments began so we first obtained cDNA partial clones of each gene by RT-PCR/cloning and then, in most cases, used these sequences to design new primers for semi-quantitative RT-PCR. The initial sets of primers were designed on regions of nucleotide sequence that were well conserved between a range of mammalian and non-mammalian species and to cover as much of the protein coding region as possible (Fig. 1).

Total RNA was extracted from the liver of a single adult possum with TRIzol reagent (Gibco BRL, Gaithersburg, MD, USA) and single-strand cDNA (ss cDNA) was synthesised using the Superscript Preamplification System (Gibco BRL) as previously described (Saunders et al. 
2001). GHR cDNA was isolated using a touchdown PCR method that involved denaturation at $94{ }^{\circ} \mathrm{C}(40 \mathrm{~s})$, annealing from $55^{\circ} \mathrm{C}$ to $41^{\circ} \mathrm{C}\left(2{ }^{\circ} \mathrm{C}\right.$ decrease every three cycles; $2 \mathrm{~min})$, and extension at $72^{\circ} \mathrm{C}(3 \mathrm{~min})$. This was followed by 15 cycles at an annealing temperature of $55^{\circ} \mathrm{C}$. Forward and reverse primers were (i) $5^{\prime}$ GGTCACCTGA RCTGGAGAC 3' and (ii) 5' GGCTAAGGCATGAT TTTGTTCAG $3^{\prime}$ and their approximate location is shown in Fig. 1. IGF-I and IGFBP-3 clones were isolated by PCR carried out for 35 cycles $\left(94{ }^{\circ} \mathrm{C}, 60 \mathrm{~s} ; 55^{\circ} \mathrm{C}, 60 \mathrm{~s}\right.$; $72{ }^{\circ} \mathrm{C}$, $60 \mathrm{~s}$ ) with primers (iii) $5^{\prime}$ AATCAGCAGTC TTCCAAC $3^{\prime}$ and (iv) $5^{\prime}$ GATC ACAGCTCCGG AAGC $3^{\prime}$ for IGF-I and primers (v) 5' TGCGARCCGT GCGACGCGCG 3' and (vi) 5' GCTTYCTGCCTTT GGAAGGGCG 3' for IGFBP-3. Reactions for all genes contained $0.5 \mu \mathrm{l}$ ss cDNA, $0.5 \mu \mathrm{M}$ each primer, $0.2 \mathrm{mM}$ each dNTP, $2 \mathrm{mM} \mathrm{MgCl}$ and $1.3 \mathrm{U}$ Taq DNA polymerase (Biotech International, Perth, Australia) in $50 \mu \mathrm{l}$ $1 \times$ Taq reaction buffer (Biotech International). PCR products were cloned and sequenced as previously described (Saunders et al. 2001). For each cDNA, two clones were sequenced in both directions. Nucleotide sequences were aligned using the AssemblyLIGN software program (Oxford Molecular Ltd, Oxford, UK) and compared with sequences in the GenBank database. Final sequences were submitted to Genbank.

\section{Semi-quantitative RT-PCR for GHR, IGF-I and IGFBP-3}

This method has been previously described by us for quantification of IGF-II mRNA expression in possum liver (Saunders et al. 2001). Extraction of total RNA from liver tissue and preparation of ss CDNA were performed as described above except that $3 \mu \mathrm{g}$ total RNA were used in the RT reaction. Control reactions were also routinely performed. These included negative controls where water was substituted for RNA and reactions in which reverse transcriptase was omitted. Initially, nonquantitative PCR was performed with ss cDNA and primers to either GHR ((vii) 5' GAGCTGGACATCG ATGAC $3^{\prime}$ and (viii) $5^{\prime}$ GACAGGTAGA CCAGTG GAC $3^{\prime}$ ), IGF-I ((ix) 5' TCRCATCTCTTCTAYCT GGC $3^{\prime}$ and (iv)), IGFBP-3 ((x) GTGCGGCGTCTAC ACSGAGCG $3^{\prime}$ and (xi) 5' GTCTTCCATTTCTCT GCG $3^{\prime}$ ) or possum $\beta$-actin ((xii) 5' CCTGAAGAGC ACCCTGTGC $3^{\prime}$ and (xiii) $5^{\prime}$ GTCAGGATCTTCAT GAG GTAG $3^{\prime}$ ) using the conditions specified above for IGF-I and IGFBP-3, except that an initial denaturation step $\left(94^{\circ} \mathrm{C}, 1 \mathrm{~min}\right)$ and final extension step $\left(72{ }^{\circ} \mathrm{C}\right.$, $10 \mathrm{~min})$ were added. PCR with these primers gave single products of the expected sizes which were $375,216,415$ and $294 \mathrm{bp}$ for GHR, IGF-I, IGFBP-3 and $\beta$-actin respectively. The relative positions of these primers are shown in Fig. 1. As no PCR products were generated when reverse transcriptase was omitted from the RT reaction, these products were presumed to be of cDNA rather than genomic DNA origin. The amount of product generated in PCR was quantified after electrophoresis through 1.2\% agarose gels containing ethidium bromide. PCR products were visualised by UV illumination and quantified using the Multi-Analyst program on the Gel Doc 2000 Gel Documentation System (Bio-Rad, Hercules, CA, USA). Each of the PCR products was quantified in terms of the area covered by the product and the pixel density.

Using adult and pouch young liver ss cDNA as template, PCR conditions with GHR, IGF-I, IGFBP-3 and $\beta$-actin primers were optimised so that the amount of product generated was directly proportional to the amount of mRNA in the original sample. Linear assay conditions were determined from a series of validation experiments in which the number of PCR cycles or the amount of starting template (total RNA and ss cDNA) used in PCR was altered. Based on results from validation experiments (data supplied for review), the following PCR conditions and reagent concentrations were used for all further semiquantitative analysis. For GHR and IGF-I individual reactions contained $0.25 \mu \mathrm{ls}$ cDNA as template, $0.5 \mu \mathrm{M}$ each primer, $0.2 \mathrm{mM}$ each dNTP, $2 \mathrm{mM} \mathrm{MgCl}_{2}$ and $1 \cdot 3 \mathrm{U}$ Taq DNA polymerase in a $50 \mu \mathrm{l}$ volume of $1 \times \mathrm{Taq}$ reaction buffer. Identical reactions were prepared when amplifying the IGFBP-3 and $\beta$-actin genes except that $0.4 \mu \mathrm{ls}$ cDNA was used. PCR conditions were the same for all genes examined $\left(31\right.$ cycles; $94{ }^{\circ} \mathrm{C}, 40 \mathrm{~s} ; 56{ }^{\circ} \mathrm{C}, 40 \mathrm{~s}$; $72{ }^{\circ} \mathrm{C}, 40$ s), along with an initial denaturation step $\left(94^{\circ} \mathrm{C}\right.$, $40 \mathrm{~s})$ and final extension step $\left(72{ }^{\circ} \mathrm{C}, 10 \mathrm{~min}\right)$.

GHR, IGF-I and IGFBP-3 mRNA expression in liver from pouch young (12-150 days post-partum) and adults $(n=4$ /group $)$ was then determined and expressed relative to $\beta$-actin, which did not show changes between age groups (Saunders et al. 2001). The precision of the semi-quantitative PCR was assessed on five replicates of an adult liver cDNA sample. The intra-assay coefficients of variation for GHR, IGF-I and IGFBP-3 were $24 \cdot 3,20 \cdot 5$ and $20 \cdot 0 \%$.

\section{Statistics}

All data were log transformed before analysis. Plasma GH concentrations, pituitary GH contents and level of gene expression from the differing age groups were compared using one-way ANOVA. Where significant effects were obtained $(P<0 \cdot 05)$, Duncan's new multiple range test was then used for pairwise comparisons.

\section{Results}

Plasma and pituitary gland GH concentrations

Mean plasma GH concentrations were highest between 12 and 100 days post-partum, measuring between about 

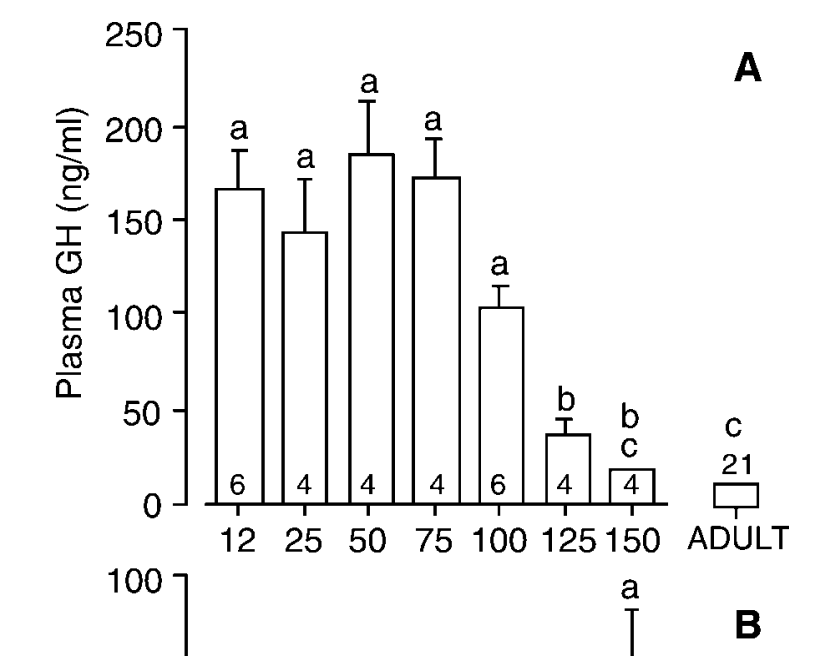

B
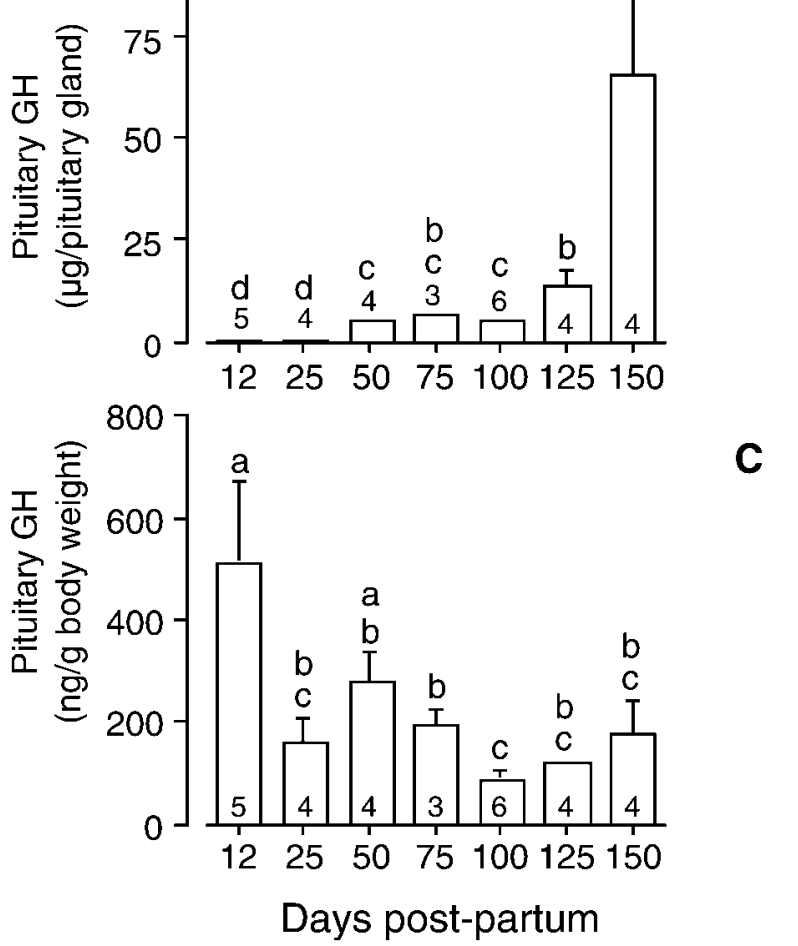

cDNA sequences of possum GHR, IGF-I and IGFBP-3 genes

The partial clones for possum GHR, IGF-I and IGFBP-3 showed a high degree of similarity with other mammalian sequences at both the nucleotide and amino acid level. The possum GHR cDNA (Genbank Accession No. AF467545) was $1705 \mathrm{bp}$ and comprised $91 \%$ of the protein coding region. The nucleotide sequence identity (amino acid identity) over this region was $79 \cdot 4 \%(77 \cdot 6 \%)$ with pig (X54429), 78.6\% (77.4\%) with rabbit (AF015252), 78.2\% (72.7\%) with human (X06562), 77.7\% (72.5\%) with sheep (M82912), 74.1\% $(67 \cdot 9 \%)$ with rat (J04811) and $71 \cdot 2 \%$ (64.9\%) with chicken (M74057).

The IGF-I partial clone (AF467543) was $260 \mathrm{bp}$, which corresponds to $118 \mathrm{bp}$ of the signal peptide and $142 \mathrm{bp}$ of the coding region. The nucleotide sequence identity (amino acid identity) over the coding region was $81.0 \%(95 \cdot 7 \%)$ with chicken (M32791), 81.0\% (89.4\%) with human (X00173), 81.0\% (89.4\%) with pig (M31175), 79.6\% (89.4\%) with sheep (M31736), 77.5\% (87.2\%) with rat (X06107), and 77.5\% (87.2\%) with Xenopus (M29857). Amino acid sequence for IGF-I is also available for one marsupial species, the Western grey kangaroo (Macropus fuliginosus) (Yandell et al. 1998). Of the 47 amino acids, deduced from possum cDNA, there was $100 \%$ identity with the kangaroo sequence.

The possum IGFBP-3 cDNA (AF467544) was 613 bp, which corresponds to $77 \%$ of the total protein coding region. The nucleotide sequence identity (amino acid identity) over this region was $72 \cdot 8 \%(77 \cdot 3 \%)$ with pig (J05228), 74.5\% (74.6\%) with human (X64875) and $72 \cdot 2 \%(71 \cdot 5 \%)$ with rat (M31837). 

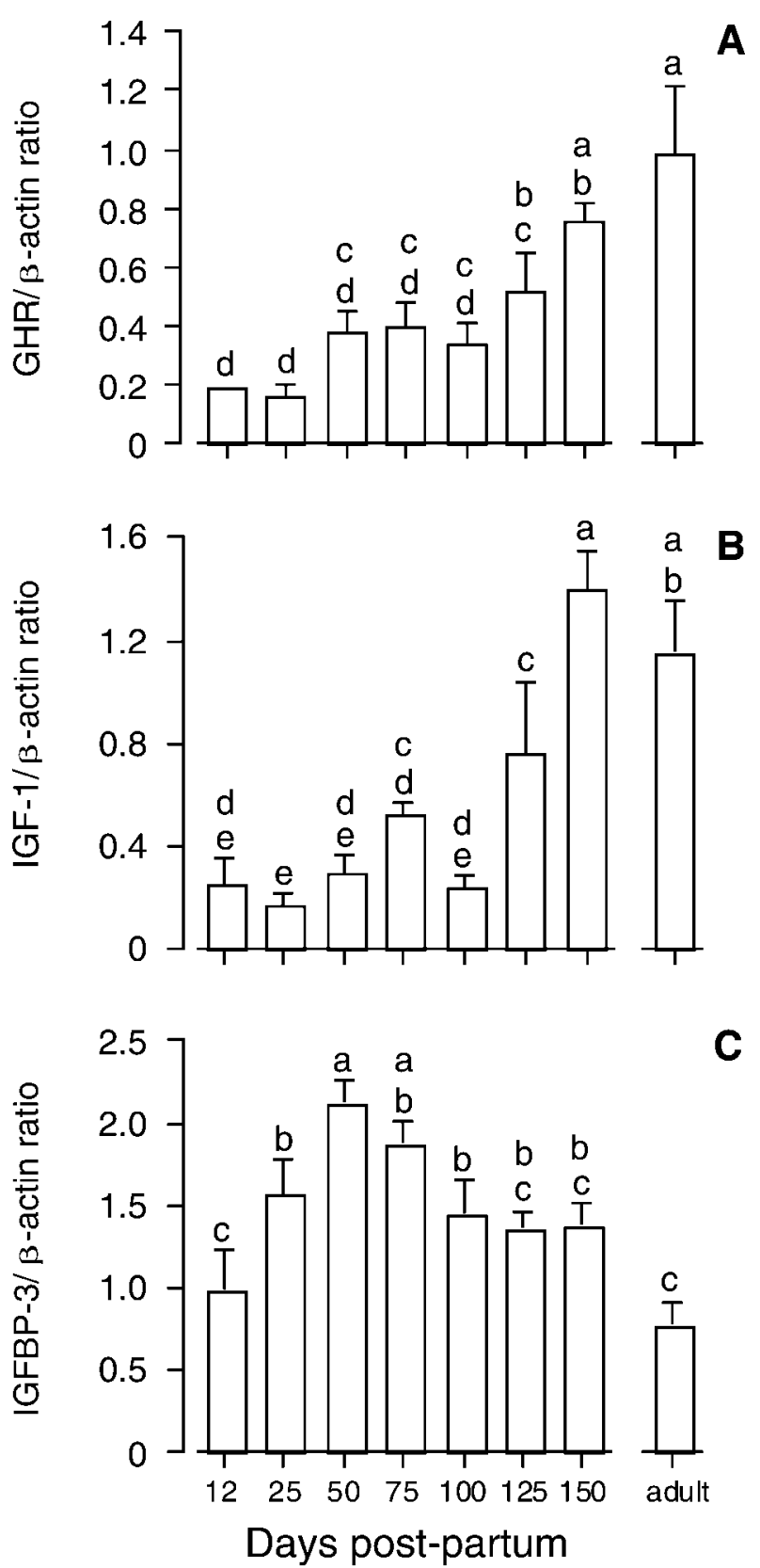

Figure 3 Pattern of liver gene expression throughout pouch life and in adult brushtail possums: (A) GHR, (B) IGF-I and (C) IGFBP-3. Values are means \pm S.E.M. ( $n=4$ /group). Where no S.E.M. is shown the value is less than the symbol depicting the mean. Groups with the same letters are not significantly different $(P>0 \cdot 05)$.

Semi-quantitative analysis of GHR, IGF-I and IGFBP-3 gene expression

The ontogeny of liver GHR, IGF-I and IGFBP-3 mRNA expression is shown in Fig. 3. For each mRNA, differences between age groups were highly significant
$(P<0 \cdot 001$; ANOVA). Liver GHR expression was low early in pouch life and then increased more than 4-fold to reach a maximum at 150 days post-partum, which was similar to that in adults (Fig. 3A). This increase was gradual during early pouch life and did not reach statistical significance $(P<0 \cdot 05)$ until day 125 (vs day 12 and day 25$)$. The developmental profile for IGF-I gene expression (Fig. 3B) was similar to that for GHR. IGF-I mRNA levels increased 5-fold between 12 and 150 days postpartum with only minor differences between age groups through to day 100 . One such increase was at day 75 $(P<0.05$ compared with day 25$)$ but it was followed by a return to lower levels of expression at day 100. Thereafter, liver IGF-I mRNA increased more rapidly to be similar to that in adults by day 150 . There was a highly significant $(P<0 \cdot 01)$ correlation between GHR and IGF-I mRNA levels $(r=0.93)$ and both also showed significant negative correlations $(r=-0.83$ and -0.89 respectively) with plasma $\mathrm{GH}(P<0 \cdot 05$ and 0.01 respectively).

In contrast to GHR and IGF-I, liver IGFBP-3 mRNA (Fig. 3C) increased significantly $(P<0 \cdot 05)$ after day 12 to peak at 50 days post-partum. Levels then gradually declined to be significantly lower by 100 days postpartum. IGFBP-3 expression in adult liver was not significantly different from that in pouch young at days 12,125 and 150 days post-partum. The were no significant correlations between IGFBP-3 and plasma GH, pituitary GH content, GHR mRNA or IGF-I mRNA.

\section{Discussion}

This study of the brushtail possum provides the first detailed account of the ontogeny of the GH/IGF-I axis during pouch life of a marsupial. Here we show that liver GHR and IGF-I mRNA expression are low early in pouch life, do not show large and sustained increases until 125 days post-partum and are similar to those in adult liver by 150 days post-partum. In contrast, we have previously shown that IGF-II gene expression is high from 12 through to 150 days post-partum and significantly above that of the adult for this entire period (Saunders et al. 2001). These results suggest that IGF-II, which is regarded as a fetal growth factor in eutherian mammals, could play a similar role in post-natal growth of marsupials during the first half of pouch life when GHR and IGF-I expression is low.

In this study we chose to examine hepatic mRNA expression of GHR, IGF-I and IGFBP-3 because GH has been shown to regulate the expression of these proteins in other mammalian species (Mathews et al. 1986, 1989, Isgaard et al. 1988, Zapf et al. 1989, Sauerwein et al. 1991, Ambler et al. 1992, Bichell et al. 1992, Baumbach \& Bingham 1995, Lemmey et al. 1997). Since the liver is a primary target for GH, expression of GHR, IGF-I and IGFBP-3 in this tissue is likely to reflect the effects of circulating GH. Our results for GHR and IGF-I, which 
are negatively correlated with plasma $\mathrm{GH}$, suggest that the possum liver is resistant to $\mathrm{GH}$ early in pouch life, possibly because GHR expression is low. In support of this explanation, plasma GH-binding protein concentration, which correlates with liver GHR levels in eutherian mammals (Mulumba et al. 1991, Ambler et al. 1992), is also low early in pouch life (days 45-87) but then increases more than 3-fold by about 120 days post-partum (Saunders et al. 2002). In eutherian mammals, the fetal liver is relatively insensitive to $\mathrm{GH}$ and only post-natally does $\mathrm{GH}$ become an important regulator of hepatic IGF-I production. This insensitivity to $\mathrm{GH}$ is thought to result from a relative absence of GHR in the liver (Gluckman 1984, Badinga et al. 1991), and as GHR expression increases post-natally (Mathews et al. 1989, Peng et al. 1996) IGF-I expression and growth become GH-dependent. In sheep, the increase in hepatic GHR and IGF-I expression that occurs in the last 10 days of gestation is due to the pre-partum rise in cortisol and thyroid hormone ( $\mathrm{Li}$ et al. 1996, Forhead et al. 2000). In the brushtail possum pouch young, plasma cortisol concentrations have not been reported but Buaboocha \& Gemmell (1995) have shown that plasma triiodothyronine and thyroxine concentrations are low up until about 60 days post-partum then gradually increase to peak at about days 100-130 post-partum. Although this increase in thyroid hormones slightly precedes the increase in hepatic GHR and IGF-I expression, further experiments would be justified to establish whether this represents a causal relationship.

In contrast to the pattern seen for GHR and IGF-I, IGFBP-3 mRNA expression peaked at 50 days postpartum then declined over the subsequent 50 days. In eutherian mammals, GH and IGF-I are thought to regulate IGFBP-3 expression (Villafuerte et al. 1996, Lemmey et al. 1997). However, if, as discussed above, the liver is resistant to GH early in pouch life, factors other than $\mathrm{GH}$ itself and IGF-I must be involved in stimulating IGFBP-3 expression between birth and 50 days post-partum. Based on research on eutherian mammals, candidates for this role would include IGF-II, acting at the type-1 IGF receptor (Villafuerte et al. 1996). In the possum, we have observed high hepatic IGF-II mRNA expression through pouch life. If IGF-II protein is also increased, either locally in the liver or in plasma, this hormone could be a key regulator of IGFBP-3 in pouch young. However, IGFBP-3 expression declines after day 75 , at a time when there is no decrease in IGF-II expression and presumably increased GH signalling through GHR as evidenced by increased GHR and IGF-I mRNA expression. Clearly further studies that include estimates of protein expression should be undertaken to resolve this apparent paradox.

We have previously reported that plasma GH concentrations in the possum pouch young are very high early in life but then decline to reach adult levels by about 96-120 days post-partum (Saunders et al. 2002). In the present study on precisely aged pouch young, plasma GH concentrations remained elevated above those in the adult until 125 days post-partum, even though they had declined from those seen in younger animals. This difference between studies is most probably due to the errors involved in estimating age from published growth curves (Lyne \& Verhagen 1957) which we used in our earlier study (Saunders et al. 2002). GH is not present in possum milk (Saunders et al. 2002), so the source of high GH concentrations in pouch young is most probably the anterior pituitary gland. In the present study we measured pituitary GH content, and in contrast to plasma concentrations there was a substantial increase through pouch life, which presumably reflects the increased total body weight, and therefore weight of pituitary tissue. In an attempt to compensate for this effect, we calculated pituitary GH content per gram body weight and although there was a significant decline after 12 days post-partum, GH content was relatively constant between 25 and 150 days postpartum. Therefore, the decline in plasma GH after 100 days post-partum is not due to decreased synthesis and/or increased storage in the pituitary gland.

Very high plasma GH concentrations also occur during development of eutherian mammals but these peak in utero or around the time of birth. For example, human and sheep fetuses have elevated GH concentrations that are well in excess of those in the adult. For humans, a major decline in GH concentrations occurs mid-gestation (Gluckman et al. 1981) while for sheep it occurs around the time of parturition (Bassett et al. 1970, Gluckman et al. 1981). In contrast in the rat, $\mathrm{GH}$ concentrations increase rapidly during late gestation, peak at birth and then decline over the next 10 days (Rieutort 1974). This decline in plasma GH levels in fetal and neonatal eutherians appears to be associated with key developmental or maturational changes such as the onset of inhibitory control by somatostatin, decreased secretion of GH-releasing hormone (Gluckman et al. 1979) and the development of the negative feedback mechanism, where increasing IGF-I concentrations act directly on the pituitary gland to decrease GH secretion (Berelowitz et al. 1981, Tannenbaum et al. 1983). Our observation in the present study of the possum, that the first significant increase in hepatic IGF-I expression coincided with the decline in plasma $\mathrm{GH}$ at 125 days post-partum, lends support to the possibility that the decline in plasma GH is also due to an increase in the negative feedback from IGF-I in this species.

In summary, this study revealed that GHR and IGF-I gene expression in the liver show an inverse relationship with plasma GH concentration. This pattern is similar to that observed in some eutherian species, except that in the possum these major changes in plasma GH and GHR and IGF-I gene expression occur much later in relation to the time of birth. Given the immaturity of the marsupial at birth, it would appear that this transition occurs at a similar developmental stage in both eutherian mammals and the possum. In contrast to GHR and IGF-I, IGFBP-3 
expression increased much earlier in pouch life than would be expected from studies of eutherian mammals.

\section{Acknowledgements}

The authors would like to thank Dr Lyn Hinds (Vertebrate Biocontrol Centre, CSIRO Division of Wildlife and Ecology, Canberra) for supplying donkey anti-guinea-pig serum used in the GH RIA, Dr Neil Wedlock (AgResearch, Wallaceville, New Zealand) for supplying the plasmid containing cDNA for the possum $\beta$-actin gene and Dr Nicholas Saunders (Centre for Immunology and Cancer Research, University of Queensland) for technical advice.

\section{References}

Ambler GR, Breier BH, Surus A, Blair HT, McCutcheon SN, Silbergeld A \& Gluckman PD 1992 The interrelationship between and the regulation of hepatic growth hormone receptors and circulating GH binding protein in the pig. Acta Endocrinologica 126 155-161.

Badinga L, Collier RJ, Thatcher WW, Wilcox CJ, Head HH \& Bazer FW 1991 Ontogeny of hepatic bovine growth hormone receptors in cattle. Journal of Animal Science 69 1925-1934.

Bassett JM, Thorburn GD \& Wallace ALC 1970 The plasma growth hormone concentration of the foetal lamb. Journal of Endocrinology 48 251-263.

Baumbach WR \& Bingham B 1995 One class of growth hormone $(\mathrm{GH})$ receptor and binding protein messenger ribonucleic acid in rat liver, GHR1, is sexually dimorphic and regulated by GH. Endocrinology 136 749-760.

Berelowitz M, Szabo M, Frohman LA, Firestone S, Chu L \& Hintz R 1981 Somatomedin-C mediates growth hormone negative feedback by effects on both the hypothalamus and pituitary. Science 212 1279-1281.

Bichell DP, Kikuchi K \& Rotwein P 1992 Growth hormone rapidly activates insulin-like growth factor I gene transcription in vivo. Molecular Endocrinology 6 1899-1908.

Buaboocha W \& Gemmell RT 1995 Thyroid gland development in the brushtail possum, Trichosurus vulpecula. Anatomical Record 243 254-260.

Curlewis JD \& McNeilly AS 1992 Purification, partial characterisation, and radioimmunoassay of prolactin and growth hormone from the Bennett's wallaby. General and Comparative Endocrinology 88 341-350.

Forhead AJ, Li J, Saunders JC, Dauncey MJ, Gilmour RS \& Fowden AL 2000 Control of ovine hepatic growth hormone receptor and insulin-like growth factor I by thyroid hormones in utero. American Journal of Physiology. Endocrinology and Metabolism 278 E1166-E1174.

Gemmell RT 1990 Seasonal breeding in two marsupials, the bandicoot, Isoodon macrourus and the brushtail possum, Trichosurus vulpecula. Advances in Comparative Endocrinology, pp 627-631. Eds A Epple, CG Stanes \& MH Stetson. New York, NY: Wiley-Liss.

Gemmell RT \& Hendrikz JK 1993 Growth rates of the bandicoot Isoodon macrourus and the brushtail possum Trichosurus vulpecula. Australian Journal of Zoology 41 141-149.

Gluckman PD 1984 Functional maturation of the neuroendocrine system in the perinatal period: studies of the somatotropic axis in the ovine fetus. Journal of Developmental Physiology 6 301-312.

Gluckman PD, Mueller PL, Kaplan SL, Rudolph AM \& Grumbach MM 1979 Hormone ontogeny in the ovine fetus. III. The effect of exogenous somatostatin. Endocrinology 104 974-978.
Gluckman PD, Grumbach MM \& Kaplan SL 1981 The neuroendocrine regulation and function of growth hormone and prolactin in the mammalian fetus. Endocrine Reviews 2 363-395.

Isgaard J, Moller C, Isaksson OGP, Nilsson A, Mathews LS \& Norstedt G 1988 Regulation of insulin-like growth factor messenger ribonucleic acid in rat growth plate by growth hormone. Endocrinology 122 1515-1520.

Lemmey AB, Glassford J, Flick-Smith HC, Holly JMP \& Pell JM 1997 Differential regulation of tissue insulin-like growth factor-binding protein (IGFBP)-3, IGF-I and IGF type 1 receptor mRNA levels, and serum IGF-I and IGFBP concentrations by growth hormone and IGF-I. Journal of Endocrinology 154 319-328.

Li J, Owens JA, Owens PC, Saunders JC, Fowden AL \& Gilmour RS 1996 The ontogeny of hepatic growth hormone receptor and insulin-like growth factor I gene expression in the sheep fetus during late gestation: developmental regulation by cortisol. Endocrinology 137 1650-1657.

Lyne AG \& Verhagen AMW 1957 Growth of the marsupial Trichosurus vulpecula and a comparison with some higher mammals. Growth 21 167-195.

Mathews LS, Norstedt G \& Palmiter RD 1986 Regulation of insulin-like growth factor I gene expression by growth hormone. PNAS 83 9343-9347.

Mathews LS, Enberg B \& Norstedt G 1989 Regulation of rat growth hormone receptor gene expression. Journal of Biological Chemistry 264 9905-9910.

Mulumba N, Massa G, Ketelslegers JM \& Maes M 1991 Ontogeny and nutritional regulation of the serum growth hormone-binding protein in the rat. Acta Endocrinologica 125 409-415.

Peng M, Pelletier G, Palin MF, Veronneau S, Le Bel D \& Abribat T 1996 Ontogeny of IGFs and IGFBPs mRNA levels and tissue concentrations in liver, kidney and skeletal muscle of pig. Growth, Development and Aging 60 171-187.

Rieutort M 1974 Pituitary content and plasma levels of growth hormone in foetal and weanling rats. Journal of Endocrinology 60 261-268.

Saunders MC, Gemmell RT \& Curlewis JD 2000 Plasma concentrations of thyroxine and growth hormone in the developing marsupial bandicoot (Isoodon macrourus). Reproduction, Fertility and Development 12 263-267.

Saunders MC, Gemmell RT \& Curlewis JD 2001 Insulin-like growth factor II cDNA cloning and ontogeny of gene expression in the liver of the marsupial brushtail possum (Trichosurus vulpecula). General and Comparative Endocrinology 121 114-124.

Saunders MC, Gemmell RT, Waters MJ \& Curlewis JD 2002 Plasma hormone and growth hormone binding protein during development in the marsupial brushtail possum (Trichosurus vulpecula). Journal of Endocrinology 173 507-515.

Sauerwein H, Breier BH, Bass JJ \& Gluckman PD 1991 Chronic treatment with bovine growth hormone upregulates high-affinity hepatic somatotropic receptors in sheep. Acta Endocrinologica 124 307-313.

Tannenbaum GS, Guyda HJ \& Posner BI 1983 Insulin-like growth factors: a role in growth hormone negative feedback and body weight regulation via brain. Science 220 77-79.

Villafuerte BC, Zhang WN \& Phillips LS 1996 Insulin and insulin-like growth factor-I regulate hepatic insulin-like growth factor binding protein-3 by different mechanisms. Molecular Endocrinology 10 622-630.

Yandell CA, Francis GL, Wheldrake JF \& Upton Z 1998 Purification, amino acid sequence and characterisation of kangaroo IGF-I. Journal of Endocrinology 156 195-204.

Zapf J, Hauri C, Waldvogel M, Futo E, Hasler H, Binz K, Guler HP, Schmid C \& Froesch ER 1989 Recombinant insulin-like growth factor I induces its own specific carrier protein in hypophysectomised and diabetic rats. PNAS 86 3813-3817.

Received 8 October 2002 Accepted 22 October 2002 